done by direct contract at the universities; for the most part, however, radio research at the universities is not formally part of the programme of the Organization. In addition to the laboratory research in Great Britain, the Organization operates outstations in the country and overseas, of which the four principal ones are: Hillhead, near Fraserburgh, Scotland, which is mainly concerned with verticalincidence ionospheric measurement, though, in addition, it is used for transmission and reception tests ; Port Stanley, Falkland Islands, and Singapore, which also are both used for vertical-incidence ionosphere work, the latter being in close contact with Raffles College, Singapore; and Winkfield, Windsor, which is concerned with the accurate measurement of direction of arrival of ionospheric waves. The establishment of further stations is being considered.

Last but not least in the activities reported by the Radio Research Board is the short account given of the service known as "Abstracts and References", a service of very long standing, which reviews contemporary literature suitable for the needs of all radio research workers, whether engaged in fundamental research or in industrial developments and applications. For many years these abstracts have been published monthly in the Wireless Engineer and also, since 1946, in the Proceedings of the Institute of Radio Engineers in New York.

The past achievements of British research in the field of radio and radar are probably well appreciated by the layman; and "Radio Research 1933-48", in the typically prosaic and modest way that characterizes official reports, gives an outline of the technical details and enhances the reputation that has been gained. There can be little doubt that the new Radio Research Organization will carry the torch in the same way.

\section{RESEARCH COUNCIL OF ISRAEL}

\section{FIRST ANNUAL REPORT}

$\mathrm{T}$ HE first annual report of the Research Council of Israel covers its activities from its establishment in June 1949 to March 31, 1950*. These activities comprise the organization and co-ordination of research in all the branches of natural science and technology; the encouragement and conduct of scientific investigations with the view of the development of industry and agriculture and the utilization of the natural resources of Israel, as well as the promotion of health and welfare; and advising the Government on planning in all fields connected with natural science and technology. The Council, which consists of seven men of seience appointed by the Prime Minister, and five representatives of the main scientific institutions of the country, with the Prime Minister as chairman, has established standing advisory committees for fundamental research, as well as industrial, agricultural, building and food research. Medical research is being considered by a sub-committee of that for fundamental research, and other sub-committees have been appointed for problems of general biology, enzymology and the utilization of wind-power and solar energy. For the present, research projects are being carried out in the estab-

* Research Council of Israel. First Annual Report for the Year ending 31 March 1950. Pp. 30. (Jerusalem: Government Printer, 1950.) lished scientific institutions, and these are being extended where necessary.

A study of the phase relationships of the important salts of the Dead Sea is reported as being carried out in the hope that the results may assist in the separa. tion of these salts by solar evaporation. The Geological Institute was established at Jerusalem in May 1949 with the main task of mapping the country on a scale of $1: 20,000$ for the purpose of determining its resources in raw materials and surface water, in addition to that of advising other Government departments in the field of geology. 'Two industrial research associations, the Citrus Concentrates Producers' Association and the Ceramics Research Association, have so far been formed, and the textile laboratory at the Standards Institution of Israel at Tel-Aviv is expected to facilitate establishment of a textile research association. Building research is directed particularly to the requirements of the new immigrants' houses and the development of new building methods which will entail the minimum use of imported materials. Besides a systematic study of climatology in relation to building and investigations on the influence of roof structure on the indoor climate of rooms on upper floors, the respective merits of concrete and bitumen for use in road construction in different parts of Israel are being studied, as well as the mechanism of the deterioration of bitumen and the physical effects of its ageing.

The percolation of water from storage ponds, the utilization of olive residues and the rate of evaporation from water surfaces are other problems under investigation, while plant investigations have concentrated mainly on the comparative growth of different strains of fibre plants under local conditions and tests of the methods applied for the industrial utilization of these plants. Local plants containing alkaloids or essential oils have also been studied, as well as the sensitivity of summer and winter plants to herbicides. Two other projects were aimed at the elimination of the serious tick-borne diseases of cattle. Problems related to the utilization of orange peel for the growth of fodder yeasts, including a study of the microorganisms which intervene in the fruit processing and of useful micro-organisms in the citrus industry, have also been investigated, and it is intended to publish detailed scientific reports on the projects in hand, either in scientific periodicals, including the Bulletin of the Council, the first issue of which is now in the press, or in the form of monographs. Three such monographs published in 1949-50 are listed in the report, together with a list of publications of the Palestine Branch for Scientific and Industrial Research, 1945-48.

\section{OVERSEAS FOOD CORPORATION}

\section{ANNUAL REPORT FOR 1949-50}

$T$ HE second annual report of the Overseas Food Corporation*, which covers the year ended March 31, 1950, has already been rendered somewhat out of date by subsequent changes in personnel, and, so far as the groundnuts scheme is concerned, by the Corporation's acceptance last autumn of the recommendations of the 'working party' which it had appointed as a result of the disappointing agricultural results at Kongwa for the second year in succession.

* Overseas Food Corporation. Annual Report and Statement of H.M. Stationery Office, 1950.) 38. 6d. net. 
This 'working party' was appointed to recommend the long-term and short-term agricultural policies to be pursued by the Corporation in this region in the light of the results achieved to date and other evidence. It was anticipated in the Corporation's report for 1949-50 that the 'working party' would have reported and that action might have been taken on its recommendations by the time the Corporation's own report was published, and it was likewise forecast that the 'working party' might rocommend a drastic reduction in arable farming for the next planting season.

Both anticipations have proved substantially correct. The "working party's' principal recommendation was that, for the three-year period beginning with planting at the end of 1950 , cultivation of groundnuts and sorghum should be confined to independent farmers. This means a total of no more than 1,200 acres, the rest of the 94,000 acres cleared being used for ranching cattle. The Corporation's acceptance of this recommendation has undoubtedly been influenced by the 'working party's' disclosure that during the past year production of $£ 100,000$ worth of erop cost $£ 600,000$, although this was due to failure of the sunflower harvest.

It may be noted here that the Kongwa 'working party' recommended in its report (available from the Overseas Food Corporation, 31 Hill Street, London, W.1) that besides organizing the area in three independent farms of $12,000,6,000$ and 3,000 acres, respectively, an additional farm of $1,000-1,500$ acres of cultivation should be placed under a manager whose operations should be directed and controlled by the Scientific Department and the Operational Research Unit, soil types for this farm being approximated as far as possible to those of the smallest farm in the cultivated area. This suggestion, which has also been adopted, is intended to assist in demonstrating whether or not the results obtained by these departments on the smaller scale can be achieved on a farming unit which could be expected to succeed economically.

The 'working party' regarded its farming proposals as in themselves experimental, but subject to limitations of staff and finance it also suggested as of special importance fundamental studies on the soil physics, including soil and water relations and particularly the retention of water in the soil under different treatments, and on soil structure and the possibilities of counteracting soil compaction, as well as physiological-ecological studies on crop plants and grasses, with particular reference to the range of root systems. A closer study of rainfall, humidity and evaporation, studies of varieties of groundnuts, sorghum and maize in relation to drought resistance, extended small-seale trials of possible alternative economic crops, particularly cotton, the study of Calidea and methods of controlling it are among other investigations suggested. It also advocated the study of soil and moisture conversion methods, including the following treatments on a typical hillside slope on red soils in which arrangements could be made for measuring soil and water surface movement and moisture contents of the soil at frequent intervals in time and space: (i) continuous cultivation with soil-conserving banks and channels, both on and off the contour; (ii) strip cropping with alternate husbandry on the basis of three years cropping and three years leys; (iii) permanent grass strip of varying width and varying intervals; (iv) bare fallowing at intervals in the rotation.
The acceptance of the main recommendations put forward in the 'working party's' report indicates that the Corporation now recognizes that the right way of cultivating crops at Kongwa has not yet been found; and, although the question may fairly be raised whether the modest scheme now proposed is worth retaining within the framework of the Overseas Food Corporation or whether it should not be transferred to the Tanganyika Government, it is clear that the future policy of the Corporation at Kongwa or elsewhere will be firmly based on scientific investigation. The present report, for example, points out that the progress of work in the three regionsKongwa, Urambo and South Province-has emphasized the importance of detailed forward reconnaissance of land before any clearing takes place. Only in this way can it be ensured that all the land cleared is suitable for cultivation in respect of its fertility, drainage and situation, and that none of it will need to be abandoned after the expense of clearing has been incurred. In Kongwa, it is admitted, the decision to clear the bush on a square-mile grid was taken and acted upon before the necessity of detailed reconnaissance was fully appreciated.

The scientific and technical work of the year is reviewed in Chapter 12 , and in the report of the Scientific Department for the crop-year 1948-49, the general summary and conclusions of which form Appendix 5. The major work undertaken by the Geological Department was the forward reconnaissance of 1,200 square miles of the Southern Province and the investigation of proposed dam sites on the Mbemkuru River for a water supply to Noli. Other work included investigation of the underground structure in relation to the yellowing of the groundnut plants in the Lubirimluga at Kongwa.

The main purpose of the investigations of the Scientific Department remains the collection of data on which may be based the development of sound systems of agriculture in the regions of Tanganyika Territory under development by the Corporation. During the season under review the experimental stations in the three regions were firmly established, with complete soil-conservation systems and mechanical equipment. Considerable progress was made in the assessment of the chemical and physical characteristics, and the classification on genetical lines, of the main soil types of all regions, particularly in the Southern Province, in collaboration with the forward reconnaissance survey.

Many experiments were laid down on the fertilizer requirements of the main crops on the main soil types, but several of these experiments were lost through severe drought. As in 1947-48, phosphorus was the only added plant nutrient which increased the yield of groundnuts. Sunflowers gave some response to phosphorus and calcium; but nitrogen caused severe seed-bed losses of plants. Addition of nitrogen greatly increased the yield of maize, especially in presence of phosphorus. Trials with individual crops were also considerably affected by the drought, especially at Kongwa. Early planting of groundnuts was shown to be of importance in all three regions, and the limited planting season available at Kongwa was again demonstrated. At Urambo, some varieties of grain sorghum yielded well, and satisfactory crops of some of the short-term maize varieties were harvested, while two varieties of soya beans showed some promise in the Southern Province.

Work on plant diseases was largely confined to Urambo. The only disease of groundnuts of serious 
economic importance at the present time is rosette disease, which was particularly heavy at Urambo in 1948-49. The investigations so far have been designed to study the biology of the aphid which transmits the disease and methods of controlling it. Attention has also been given to diseases causing losses in the seedbed and of the young seedlings, entailing the study of a range of seed-dressing materials. Besides the study of the insect vector of rosette disease, the main entomological work was concerned with the pollina. tion of sunflowers. The control of the blue bug pest of sorghum and sunflower was also studied. Analysis of the oil-content of developing groundnuts from experimental plots indicate that the smaller kernels have a lower oil-content and that shrivelled kernels show a lower proportion of oil than smooth ones of the same size-groups. Conversely, in Tanganyika, the larger the seed the more vigorous the seedling and the sooner it emerges from the soil.

The Scientific Department maintains close relations with Government officials engaged on similar work in East Africa by means of the Corporation's Scientific Committee, of which the director and deputy director of the East African Agricultural and Forestry Research Organization and the director of agriculture, Tanganyika Territory, are members. The Department is also linked with the Agricultural, Research and Technical Department in London, and, in addition, a close liaison is maintained with other scientific and technical work outside the Corporation, at home and overseas. While for the time being the existence of such a vigorous Scientific Department may well have a stimulating effect on the agricultural research at present being co-ordinated in East Africa under the East African High Commission, the nature of the work is such that the question may well arise, ultimately, whether it would not be more effectively prosecuted, with less risk of duplicated effort, under the auspices of the East African Agricultural and Forestry Research Organization when that has been fully developed.

Most of the work of the Operational Research Unit in 1949 dealt with field trials of agricultural equip ment in use or of potential value, particularly planting-machines and machines for harvesting groundnuts, the two operations where there is most need of improvement. Work on ridge planting of groundnuts gave promising results under close supervision, and modifications to combines for harvesting sunflowers have proved of great practical value. Considerable attention continued to be given to the machines used in, and the techniques of, land-clearing, and as a result of investigations of chain-felling technique and root-cutting the manufacture of two prototype machines was put in hand. The bias of future work is to be towards an assessment of the performance of equipment during normal operations.

Included as Part 5 of the Overseas Food Corporation's report is the second annual report of the Queensland-British Food Corporation for 1949-50. The area of 29,286 acres sown to sorghum gave a final yield of about 316,000 bushels or 80 per cent of that originally estimated, due partly to the succession of extremely heavy frosts in May, but principally to lodging, especially in the variety "kalo". Results obtained on an area of about a hundred acres sown to sunflowers justified the opinion that this crop will be of value, not only to provide vegetable protein for feeding to pigs, but also as a rotation crop with grain sorghum. Despite severe frosting and local flood damage to the plot, about $400 \mathrm{lb}$. of seed per acre was harvested. The area sown to sorghum was increased to 66,432 acres and most crops are making satisfactory progress, generally the later-planted crops, and the areas re-sown, promising the best results. A scientific committeo is being established on which it is proposed that the University of QueensIand, the Queensland Department of Agriculture and Stock, and the Commonwealth Scientific and Industrial Research Organization should be represented, under the chairmanship of the deputy chairman of the Queensland-British Food Corporation.

\section{THE COCO-DE-MER OF THE SEYCHELLES}

7 HE coco-de-mer palm of the Seychelles, Lodoicea seychellarum (or, to give it an earlier but misleading name, $L$. maldivica), has for several reasons long been familiar as one of the most remarkable of endemic plants; but while some things about it are well enough known, others are not, and Mr. Durocher Yvon, who has a wide first-hand knowledge of the plant, has done a useful service in re-stating the facts in a recent well-illustrated paper*.

The Seychelles comprise two groups of islands, one coralline and one granitic, and Lodoicea is native only on two of the latter, Praslin and one of its satellite islands, Curieuse, which together have an area of less than twenty square miles. There are traces of its former existence on a second satellite, Round Island. Formerly it must have had a very complete and even distribution over these islands; but to-day it occurs mostly in scattered groups or as relic trees. It still grows, however, under more or less natural conditions in the Vallee de Mai and in one or two other nearby reserves, on Praslin, where there are estimated to be four thousand trees. The palm grows in a deep red lateritic soil derived from granite, and under natural conditions is definitely a hill-side species which is seen at sea-level only on spurs of granite. It does not grow, as the coconut does, in maritime sand.

The fruits, which are often but mistakenly called double-coconuts, are the best-known part of the tree's story, and are said to be the largest fruits known, often being eighteen inches long and more than three feet round. Each is a fibrous drupe with a bilobed endocarp containing, when mature, an endosperm of ivory-like consistency. In this state the fruit generally weighs about $25-40 \mathrm{lb}$., though abnormal specimens of $90 \mathrm{lb}$. have been recorded. The specific gravity of the fruit when ready to germinate is about $\mathbf{l} \cdot 2$, so that it sinks in both freshand sea-water; but if the endosperm decays it will float, and it is in this non-viable condition that it has been cast up on the shores of the Maldives and of India. Lodoicea is diccious; may reach a height of $100 \mathrm{ft}$.; takes twenty-five years to mature, and the fruits take more than six years to ripen. Wind pollination is the rule; but the flowers are visited by insects.

There is much else of interest in Mr. Durocher Yvon's paper, especially perhaps his accounts of the mature root system and of the mothod of germination; but this note is concerned rather with stressing the geographical problem that Lodoicea presents. Here

* Durocher Yvon, F., "Seychelles Botanical Treasure ; the "Cocode-Mer' Palm (Lodoicea' malaivica Pers.)", La Revue Agricole de l'Ile Maurice, 26, 69 (1947). 